\title{
Fungicides Used Alone, in Combinations, and in Rotations for Managing Gladiolus Rust in Mexico
}

A. J. Valencia-Botín, Universidad de Guadalajara, Centro Universitario de la Ciénega, Col. Lindavista, Ocotlán, Jalisco, México 47810; S. N. Jeffers, School of Agricultural, Forest, and Environmental Sciences, Clemson University, Clemson, SC 29634; C. L. Palmer, IR-4 Project, Princeton, NJ; and J. W. Buck, Department of Plant Pathology, University of Georgia, Georgia Station, Griffin 30223

\begin{abstract}
Valencia-Botín, A. J., Jeffers, S. N., Palmer, C. L., and Buck, J. W. 2013. Fungicides used alone, in combinations, and in rotations for managing gladiolus rust in Mexico. Plant Dis. 97:1491-1496.

Gladiolus rust, caused by Uromyces transversalis, is a quarantinesignificant pathogen in the United States. However, the fungus is endemic to commercial gladiolus-producing areas in Mexico and has been intercepted frequently on gladiolus plants entering the United States for the cut-flower market. The present study assessed 15 fungicide active ingredients (five quinone outside inhibitors: azoxystrobin, fluoxastrobin, kresoxim-methyl, pyraclostrobin, and trifloxystrobin; six triazoles: cyproconazole, difenoconazole, epoxiconazole, myclobutanil, propiconazole, and tebuconazole; three succinate dehydrogenase inhibitors: boscalid, flutolanil, and oxycarboxin; and one broad-spectrum protectant: chlorothalonil) and one plant activator, acibenzolar-Smethyl, applied alone, in combinations, and in various rotations for efficacy against $U$. transversalis on field-grown gladiolus plants in Mexico. Experiments were conducted in 2010, 2011, and 2012 in commercial fields in Atlixco and Santa Isabel Cholula in Puebla and

Cuautla and Tlayacapan in Morelos. Fungicides were applied at 2 week intervals starting when plants had three full leaves. Disease severity was recorded each week for at least 7 weeks after the first application. Under high disease pressure in 2010, fungicides were less effective than in 2011 and 2012, when disease pressure was not as high. In all 3 years, most fungicide treatments significantly reduced disease severity. Triazoles were more effective than quinone outside inhibitors when applied as individual products in 2010, and combinations of two fungicides in different mode-of-action groups were more effective than fungicides applied individually in 2011. In 2012, rotations of fungicides, either with individual products or with combinations of two products, provided excellent rust management. Reducing disease development by $U$. transversalis on commercial gladiolus plants in Mexico will reduce the potential for introducing this pathogen on cut flowers into the United States.
\end{abstract}

Uromyces transversalis (Thüm.) G. Winter, which causes rust on gladiolus plants (species and cultivars of Gladiolus L.), is considered to be a pathogen of quarantine significance in the United States. U. transversalis also infects other members of the Iridaceae family, including species in the genera Crocosmia, Tritonia, and Watsonia $(1,8)$. Species of Gladiolus are grown in the United States as ornamental plants for sale as cut flowers and for aesthetic beauty in commercial and residential landscapes. In 2009, the U.S. farm gate value of gladiolus cut-flower production was \$24 million (2009 Census of Horticultural Specialties, U.S. Department of Agriculture National Agricultural Statistics Services), with the majority of production occurring in Florida. In the United States, gladiolus plants infected with $U$. transversalis have been repeatedly intercepted in commercial shipments and passenger baggage entering the United States from Mexico and Brazil (13). Introductions of $U$. transversalis occurred in California and Florida in 2006, with the fungus becoming established on two commercial farms in Florida (2,22). Detection resulted in mandatory quarantine and eradication procedures (18), at great expense to growers.

Gladiolus flowers are imported into the United States from several countries, including Mexico. U. transversalis is endemic in commercial gladiolus production areas of Mexico (A. J. ValenciaBotín, personal observation) and, thus, Mexican imports are a potential source of introductions to the United States. Gladiolus is cultivated on about 3,611 ha, primarily in seven states in the central and eastern regions of Mexico (states of Guerrero, Mexico, Mi-

Corresponding author: J. W. Buck, E-mail: jwbuck@uga.edu

Accepted for publication 23 May 2013.

http://dx.doi.org/10.1094/PDIS-03-13-0272-RE

(C) 2013 The American Phytopathological Society choacán, Morelos, Oaxaca, Puebla, and Veracruz). Mexican farm gate value for gladiolus production was $\$ 55.7$ million in 2010 (23). Gladiolus rust was detected in the states of Mexico, Puebla, and Morelos (21) in November 2004 and in eastern Michoacán in 2005 (19). Subsequent studies showed that the pathogen had spread to the main production areas of Mexico (13). Gladiolus rust in Mexico results in economic losses due to a limitation on export of flower spikes to other countries, including the United States and the European Union. In 2004, upon detection of rust pustules on leaves of some shipments at ports in California and Texas by personnel with the Plant Protection and Quarantine program of the USDA-Animal and Plant Health Inspection Service, the United States government suspended imports of gladiolus spikes from Mexico. After negotiations between the USDA and the Department of Plant Protection of Mexico, it was agreed that shipments of gladiolus flowers without leaves could be sent from Mexico to the United States to minimize the risk of introductions of $U$. transversalis $(18,21)$.

Infection by $U$. transversalis can result in total crop loss and make cut-flower cultivation not feasible without the use of fungicides (17). Because $U$. transversalis has become endemic in commercial gladiolus production areas of Mexico, preliminary investigations were conducted to determine the best fungicide active ingredients for the management of this disease (20). Based on these limited studies, Mexican growers were advised to use the triazole fungicide bitertanol or the following combinations of succinate dehydrogenase inhibitor (SDHI), triazole, and quinone outside inhibitor (QoI) active ingredients: oxycarboxin + tebuconazole, oxycarboxin + trifloxystrobin, or tebuconazole + epoxiconazole (21). Triazole fungicides along with products containing the active ingredients chlorothalonil (a broad-spectrum protectant) and azoxystrobin (a QoI) have been the primary fungicides applied for gladiolus rust in Florida in recent years (T. S. Schubert, personal communication). 
The objective of this study was to evaluate the efficacies of a plant activator and fungicides with different active ingredients in several mode-of-action groups for the management of rust on fieldgrown gladiolus plants. Sixteen active ingredients applied as individual products, as combinations of two products, and as rotations of different products or combinations were used in trials conducted in commercial gladiolus fields in Mexico from 2010 to 2012 to identify fungicides that will be effective for long-term management of gladiolus rust. Preliminary reports have been published $(26,27)$.

\section{Materials and Methods}

Experimental design. All trials were conducted in commercial gladiolus fields naturally infected with $U$. transversalis in southcentral Mexico: Cuautla, Morelos and Atlixco, Puebla in fall 2010; Tlayacapan, Morelos in spring 2011; and Cuautla, Morelos and Santa Isabel Cholula, Puebla in fall 2011 and 2012. Gladiolus corms were planted $30 \mathrm{~cm}$ apart in rows with approximately $1 \mathrm{~m}$ between rows. An experimental unit included all plants in a plot that measured $3 \mathrm{~m} \times 3 \mathrm{~m}$ and spanned three rows. Trials utilized a randomized complete block design with one replication of each treatment in each of four blocks; therefore, four replicate plots of each treatment were used in each trial. Fungicides were applied with a $\mathrm{CO}_{2}$-pressurized backpack sprayer equipped with a fournozzle spray boom (Model E; R\&D Sprayers) and a handheld boom fitted with TJ8001 VC nozzles that delivered 470 liters/ha at $175 \mathrm{kPa}$. Fungicide applications in each trial were initiated at approximately the third-leaf stage of plant growth and were made four times at 2-week intervals, except in the spring 2011 trials, when plants received five applications. All trials included a control treatment in which plants were not treated with fungicides.

Fungicides and plant activator treatments. In all, 16 active ingredients in 15 fungicide products and one plant activator product (Actigard) were evaluated (Table 1). One fungicide product contained a mixture of two active ingredients (boscalid and pyraclostrobin). The active ingredients tested belonged to five mode-ofaction groups-each with a unique Fungicide Resistance Action Committee (FRAC) code. Fungicides with the same FRAC code have similar chemistries and the same mode of action (http://www.frac.info/); therefore they affect target fungi in a similar manner. Fourteen of the active ingredients belonged to three mode-of-action groups; six were demethylation inhibitors (DMIsmore specifically, triazoles), five were QoIs (also known as strobilurins), and three were SDHIs (Table 1).
Field experiments. A separate experiment was conducted each year with two (in 2010 and 2012) or three (in 2011) trials at different locations. Disease development was monitored for 7 weeks in all experiments, except for the experiment conducted in spring 2011, in which disease was monitored for 10 weeks. In fall 2010 , field trials included 11 fungicide treatments with individual products and these were applied at two locations (Table 2). The first application was 25 September and the final application was 6 November, when the first gladiolus flowers were harvested. In 2011, 14 treatments were evaluated, including one with the plant activator acibenzolar-s-methyl, five with individual fungicides, and eight with combinations of two fungicides (Table 3). In the spring trial, the first treatment application was on 19 March and the last application was on 14 May. In the fall 2011 field trials, applications were initiated on 17 September and ended on 29 October, and the final disease assessment was made on 5 November. In 2012, nine treatments were used to compare rotations of fungicides that included six rotations with fungicide combinations and three rotations with individual fungicides (Table 4). Initial applications were made on 7 September and the last applications were made on 19 October.

Data collection and analysis. Disease assessments were initiated 1 week after the first treatment application in all trials. Disease severity was assessed weekly by visually estimating the percentage of the foliage within each plot of plants with rust symptoms and signs; then, this percentage was converted to a 12point scale, where $1=0,2=0$ to $3,3=3$ to $6,4=6$ to $12,5=12$ to $25,6=25$ to $50,7=50$ to $75,8=75$ to $87,9=87$ to $94,10=94$ to $97,11=97$ to $100,12=100 \%$ (17). For each trial, mean disease ratings from all dates were converted to area under the disease progress curve (AUDPC) to examine treatment effects through the season (25). Disease progress was followed until the start of flower harvest (i.e., 7 to 10 weeks). AUDPC and average disease severity values on two dates in each trial were analyzed independently by one-way analysis of variance using the general linear models procedure (PROC GLM) of SAS (version 9.2; SAS Institute) statistical software. Individual treatment means were separated by Fisher's protected least significant difference with $P=0.05$ so that the most effective fungicide treatments could be identified, and single-degree-of-freedom linear contrasts were calculated to compare specific groups of treatments.

\section{Results}

Based on AUDPC values, there was a significant $(P<0.0001)$ treatment effect and fungicide treatments were effective $(P \leq$

Table 1. Fungicides applied to field-grown gladiolus plants in Mexico to manage rust caused by Uromyces transversalis in 2010 to 2012

\begin{tabular}{|c|c|c|c|c|c|c|}
\hline \multicolumn{2}{|c|}{ FRAC listing $^{w}$} & \multirow[b]{2}{*}{ Active ingredient } & \multirow[b]{2}{*}{ Trade name ${ }^{x}$} & \multirow[b]{2}{*}{ Rate $^{\mathbf{y}}$} & \multirow[b]{2}{*}{ Formulation $^{z}$} & \multirow[b]{2}{*}{ Source } \\
\hline MOA group & Code & & & & & \\
\hline Benzothiadiazole & $\mathrm{P}$ & Acibenzolar-S-methyl & Actigard & $0.075 \mathrm{~g}$ & $50 \mathrm{WDG}$ & Syngenta México \\
\hline Chloronitrile & M5 & Chlorothalonil & Daconil 2787 & $3.75 \mathrm{~g}$ & 75 WDG & Syngenta México \\
\hline \multirow[t]{6}{*}{ DMIs } & 3 & Cyproconazole & Alto & $1.00 \mathrm{ml}$ & $8.9 \mathrm{SC}$ & Syngenta México \\
\hline & & Difenoconazole & Score & $1.25 \mathrm{ml}$ & $24.6 \mathrm{EC}$ & Syngenta México \\
\hline & & Epoxiconazole & Opus & $1.88 \mathrm{ml}$ & $12 \mathrm{SC}$ & BASF Mexicana \\
\hline & & Myclobutanil & Rally & $0.20 \mathrm{~g}$ & $40 \mathrm{WP}$ & Dow Agrosciences de Mexico \\
\hline & & Propiconazole & Tilt & $2.25 \mathrm{ml}$ & $25.5 \mathrm{EC}$ & Syngenta México \\
\hline & & Tebuconazole & Tebucur & $1.50 \mathrm{ml}$ & $25 \mathrm{EW}$ & Helm de Mexico \\
\hline \multirow[t]{5}{*}{ QoIs } & 11 & Azoxystrobin & Amistar Gold & $0.75 \mathrm{~g}$ & 17.96 WDG & Syngenta México \\
\hline & & Fluoxastrobin & Disarm M & $1.93 \mathrm{ml}$ & $40.3 \mathrm{SC}$ & Arysta LifeScience North America LLC \\
\hline & & Kresoxim-methyl & Stroby & $0.63 \mathrm{~g}$ & $50 \mathrm{WDG}$ & BÄSF Mexicana \\
\hline & & Pyraclostrobin & Headline & $1.00 \mathrm{ml}$ & $23.6 \mathrm{EC}$ & BASF Mexicana \\
\hline & & Trifloxystrobin & Flint & $0.63 \mathrm{~g}$ & $50 \mathrm{WDG}$ & Bayer de Mexico \\
\hline \multirow[t]{2}{*}{ SDHI } & 7 & Flutolanil & Moncut & $5.00 \mathrm{~g}$ & $50 \mathrm{WP}$ & Arysta LifeScience Mexico \\
\hline & & Oxycarboxin & Plantvax & $3.75 \mathrm{~g}$ & $75 \mathrm{WP}$ & Chemtura Corporation México \\
\hline SDHI + QoI & $7+11$ & Boscalid + pyraclostrobin & Cabrio C & $2.00 \mathrm{~g}$ & $25.2+12.8 \mathrm{WDG}$ & BASF Mexicana \\
\hline
\end{tabular}

${ }^{\text {w } F R A C ~=~ F u n g i c i d e ~ R e s i s t a n c e ~ A c t i o n ~ C o m m i t t e e ~(h t t p: / / w w w . f r a c . i n f o /), ~ M O A ~=~ m o d e ~ o f ~ a c t i o n, ~ D M I ~=~ d e m e t h y l a t i o n ~ i n h i b i t o r, ~ Q o I ~=~ q u i n o n e ~ o u t s i d e ~}$ inhibitor, and SDHI = succinate dehydrogenase inhibitor.

$\mathrm{x}$ Trade names for products marketed and sold in Mexico and used in this study.

${ }^{y}$ Application rate (amount/liter).

${ }^{z}$ Percentages of active ingredients in commercial products formulated as an emulsifiable concentrate (EC), emulsion in water (EW), soluble concentrate (SC), water-dispersible granules (WDG), or wettable powder (WP). 
0.0003 ) at reducing disease severity compared with the nontreated control treatment in all seven trials (Tables 2-4). In addition, there were significant differences among individual treatments in each trial (Tables 2-4).

Fall 2010 (Table 2). Disease pressure was high at both locations (Cuautla, Morelos and Atlixco, Puebla), with rust symptoms observed at the first rating (1 October). The percentage of foliage with disease symptoms and signs was 44 to $49 \%$ on plants in the nontreated control plots on 16 October and increased to 75 to $77 \%$ by the end of the trials. On the third (16 October) and seventh (13 November) weeks of the trials, plants in all fungicide-treated plots had significantly less foliage disease than plants in the nontreated control plots at both locations. Disease severity on 13 November was lowest in plots sprayed with epoxiconazole, propiconazole, or tebuconazole at Cuautla, and these three treatments also had three of the lowest AUDPC values. At Atlixco, disease severity on 13 November was lowest in plots sprayed with epoxiconazole, tebuconazole, and trifloxystrobin, and the epoxiconazole treatment had the lowest AUDPC value. When the four DMI treatments were compared with the five QoI treatments by a linear contrast, plants treated with DMI fungicides (mean AUDPC values of 34.3 at Cuautla and 37.5 at Atlixco) had less foliage disease than plants treated with QoI fungicides (mean AUDPC values of 37.7 at Cuautla and 39.6 at Atlixo) at both locations (Table 2). This difference between DMI and QoI fungicides was evident in foliage disease assessments made at Atlixco on both 16 October and 13 November and at Cuautla on 13 November. Comparisons between other groups of fungicides were not significant.

Spring 2011 (Table 3). Disease pressure was low in Tlayacapan, with rust not observed until the seventh week; therefore, the trial was maintained for 10 weeks. On 28 May, the percentage of foliage with disease symptoms and signs was $9.8 \%$ in the noninoculated control plots. The mean percentage of foliage with symptoms and signs was $<7 \%$, but disease severity on plants in plots receiving the most treatments (11 of 14) was significantly less than that on plants in the control plots. In the assessment on 28 May, disease severity on plants sprayed with three of the fungicide treatments (difenoconazole, epoxiconazole, and fluoxastrobin + myclobutanil) was similar to that on plants in the nontreated control plots. In addition, five treatments (difenoconazole, epoxiconazole, fluoxastrobin + myclobutanil, chlorothalonil + epoxiconazole, and chlorothalonil + propiconazole) did not significantly reduce AUDPC compared with the nontreated control treatment. The three combination treatments containing azoxystrobin had the lowest amount of diseased foliage and the lowest AUDPC values but seven other fungicide treatments produced similar levels of disease management that were not significantly different. When groups of treatments were compared by single-degree-of-freedom linear contrasts, only the three combination treatments containing a DMI fungicide and azoxystrobin were consistently better than other combination treatments containing DMI fungicides.

Fall 2011 (Table 3). Disease pressure was low on 8 October in both locations. At Cuautla, disease was not observed in plots treated with 12 of the 14 fungicide treatments, plants in the nontreated control plots had only $1.3 \%$ of foliage with rust symptoms and signs, and no differences among treatments were found. In the plots at Santa Isabel Cholula, disease was not observed in plots sprayed with four of the fungicide treatments, disease severity was $7 \%$ in the nontreated control plots, and some differences among treatments were observed. However, disease pressure increased throughout the trial period; the percentage of foliage with disease was 43 and $59 \%$ on plants in nontreated control plots at Cuautla and Santa Isabel Cholula, respectively, on 5 November. A significantly higher percentage of foliage disease was observed 5 November with the chlorothalonil (Cuautla) and the chlorothalonil and acibenzolar-s-methyl (Santa Isabel Cholula) treatments compared with the other fungicide treatments. All treatments significantly reduced AUDPC compared with the nontreated controls at both locations, with the exception of the chlorothalonil and acibenzolars-methyl treatment at Santa Isabel Cholula.

When specific groups of fungicides were compared using linear contrasts, foliage disease and AUDPC values consistently were lower in plots sprayed with the eight fungicide combinations than

Table 2. Percentage of foliage with rust symptoms caused by Uromyces transversalis and area under disease progress curves (AUDPC) after four fungicide applications at 2-week intervals were made to gladiolus plants growing in commercial fields at two locations in Mexico in $2010^{\mathrm{w}}$

\begin{tabular}{|c|c|c|c|c|c|c|}
\hline \multirow[b]{3}{*}{ Fungicide active ingredient } & \multicolumn{3}{|c|}{ Cuautla, Morelos } & \multicolumn{3}{|c|}{ Atlixco, Puebla } \\
\hline & \multicolumn{2}{|c|}{ Foliage disease $(\%)^{x}$} & \multirow[b]{2}{*}{ AUDPC $^{\mathbf{y}}$} & \multicolumn{2}{|c|}{ Foliage disease $(\%)^{x}$} & \multirow[b]{2}{*}{ AUDPCy } \\
\hline & 16 October & 13 November & & 16 October & 13 November & \\
\hline Oxycarboxin & $16.5 \mathrm{c}$ & $44.0 \mathrm{c}$ & $36.1 \mathrm{cdef}$ & $27.5 \mathrm{bcd}$ & 37.8 cde & $40.1 \mathrm{bc}$ \\
\hline Epoxiconazole & $21.3 \mathrm{bc}$ & $23.3 \mathrm{~d}$ & $33.4 \mathrm{f}$ & $17.3 \mathrm{e}$ & $22.5 \mathrm{f}$ & $34.5 \mathrm{e}$ \\
\hline Myclobutanil & $19.0 \mathrm{bc}$ & $49.3 \mathrm{bc}$ & 36.4 cde & $28.0 \mathrm{bcd}$ & $48.8 \mathrm{~b}$ & $40.8 \mathrm{~b}$ \\
\hline Propiconazole & $17.0 \mathrm{c}$ & $29.8 \mathrm{~d}$ & $33.8 \mathrm{ef}$ & $24.0 \mathrm{de}$ & 34.8 cde & $38.3 \mathrm{~cd}$ \\
\hline Tebuconazole & $17.8 \mathrm{bc}$ & $28.8 \mathrm{~d}$ & $33.4 \mathrm{f}$ & $23.0 \mathrm{de}$ & $31.3 \mathrm{ef}$ & $37.0 \mathrm{~d}$ \\
\hline Azoxystrobin & $13.8 \mathrm{c}$ & $45.5 \mathrm{bc}$ & $35.6 \mathrm{def}$ & $29.3 \mathrm{bcd}$ & $48.3 \mathrm{~b}$ & $40.3 \mathrm{bc}$ \\
\hline Fluoxastrobin & $19.5 \mathrm{bc}$ & $58.5 \mathrm{~b}$ & $36.8 \mathrm{bcd}$ & $26.8 \mathrm{bcd}$ & $43.5 \mathrm{bc}$ & $39.8 \mathrm{bc}$ \\
\hline Kresoxim-methyl & $27.8 \mathrm{bc}$ & $51.8 \mathrm{bc}$ & $37.4 \mathrm{bcd}$ & $28.5 \mathrm{bcd}$ & $41.3 \mathrm{bcd}$ & $40.1 \mathrm{bc}$ \\
\hline Trifloxystrobin & $20.0 \mathrm{bc}$ & $51.3 \mathrm{bc}$ & $39.3 \mathrm{~b}$ & $24.8 \mathrm{~cd}$ & $32.5 \mathrm{de}$ & $38.4 \mathrm{~cd}$ \\
\hline Pyraclostrobin & $26.8 \mathrm{~b}$ & $53.8 \mathrm{bc}$ & $38.6 \mathrm{bc}$ & $31.8 \mathrm{bc}$ & 39.0 cde & $39.5 \mathrm{bc}$ \\
\hline Boscalid + pyraclostrobin & $20.0 \mathrm{bc}$ & $51.0 \mathrm{bc}$ & $37.9 \mathrm{bcd}$ & $32.8 \mathrm{~b}$ & $41.3 \mathrm{bcd}$ & $40.9 \mathrm{~b}$ \\
\hline Nontreated control & $48.5 \mathrm{a}$ & $76.8 \mathrm{a}$ & $43.4 \mathrm{a}$ & $43.8 \mathrm{a}$ & $75.3 \mathrm{a}$ & $43.3 \mathrm{a}$ \\
\hline $\operatorname{LSD}(P=0.05)$ & 9.4 & 14.2 & 2.8 & 7.0 & 8.8 & 2.3 \\
\hline \multicolumn{7}{|l|}{ One-way ANOVA $(P>F)^{\mathrm{z}}$} \\
\hline Treatments & $<0.0001$ & $<0.0001$ & $<0.0001$ & $<0.0001$ & $<0.0001$ & $<0.0001$ \\
\hline \multicolumn{7}{|l|}{ Contrasts } \\
\hline 11 treatments vs. control & $<0.0001$ & $<0.0001$ & $<0.0001$ & $<0.0001$ & $<0.0001$ & 0.0003 \\
\hline 4 DMIs vs. 5 QoIs & 0.4177 & $<0.0001$ & $<0.0001$ & 0.0045 & 0.0040 & 0.0008 \\
\hline Oxycarboxin vs. 4 DMIs & 0.5425 & 0.0440 & 0.0892 & 0.1255 & 0.3420 & 0.0085 \\
\hline Oxycarboxin vs. 5 QoIs & 0.2661 & 0.1314 & 0.1987 & 0.8020 & 0.3738 & 0.5546 \\
\hline Pyraclostrobin vs. pyraclostrobin + boscalid & 0.1534 & 0.6890 & 0.5902 & 0.7815 & 0.6213 & 0.2342 \\
\hline
\end{tabular}

${ }^{\mathrm{w}}$ Fungicides were applied on 25 September, 9 October, 23 October, and 6 November.

${ }^{\mathrm{x}}$ Foliage disease means are from all plants in four replicate plots. Means were separated with Fisher's protected least significant difference (LSD) at $P=$ 0.05 ; means in each column followed by the same letter are not significantly different.

y AUDPC was converted from a rust severity scale (1 to 12) following the methods of Shaner and Finney (24).

${ }^{z}$ Each datum set was analyzed by one-way analysis of variance (ANOVA) with single-degree-of-freedom linear contrasts used for comparisons of specific treatments. $\mathrm{DMI}=$ all active ingredients that are demethylation inhibitors, $\mathrm{QoI}=$ all active ingredients that are quinone outside inhibitors, and $P>F$ is the probability of a greater $F$ value occurring. 
in the plots sprayed with the six single fungicides; however, differences among different groups of combination treatments were not significant. In addition, among the single product treatments, foliage disease and AUDPC values consistently were lower in plots treated with the three DMI fungicides than in plots treated with chlorothalonil or flutolanil. Disease severity also was lower in plots treated with single fungicides than in plots treated with the plant activator acibenzolar-s-methyl at Santa Isabel Cholula.

Fall 2012 (Table 4). Disease pressure was lower at the Cuautla location (35\% of foliage with symptoms) compared with the Santa Isabel Cholula location (82\% of foliage with symptoms) on 26 October. All fungicide treatments significantly reduced percent foliage disease and AUDPC values at both locations. Despite the high disease pressure at Santa Isabel Cholula, foliage disease in all fungicide-treated plots was $<5 \%$ on 26 October. A comparison of the three rotations with single fungicides and the six rotations of fungicide combinations was only significant for foliage disease on 28 September at Santa Isabel Cholula.

\section{Discussion}

All of the products tested in this study-including 15 fungicide active ingredients and one plant activator-provided some level of rust management on field-grown gladiolus plants at four locations in south-central Mexico over a 3-year period (2010 to 2012). Several of these active ingredients - applied as individual products, in two-product combinations, and as rotations of individual products or two-product combinations-provided very good to excellent management of rust under field conditions, including triazole, strobilurin, and SDHI fungicides. In particular, combinations of a triazole fungicide with a strobilurin fungicide and rotating to a different product or combination of products before each application provided the most effective disease management. Disease management with the plant activator acibenzolar-s-methyl was not consistent among the three trials conducted in 2011. Under higher disease pressure in 2010 compared with 2011 and 2012, fungicides appeared to be less effective but only individual products were evaluated in the two trials conducted in 2010. Better disease man-

Table 3. Percentage of foliage with rust symptoms caused by Uromyces transversalis and area under disease progress curves (AUDPC) after fungicides and combinations of fungicides were applied as rotations to gladiolus plants growing in commercial fields at three locations in Mexico in spring and fall $2011^{\mathrm{w}}$

\begin{tabular}{|c|c|c|c|c|c|c|c|c|}
\hline \multirow[b]{3}{*}{ Fungicide active ingredient ${ }^{w}$} & \multicolumn{2}{|c|}{ Tlayacapan, Morelos } & \multicolumn{3}{|c|}{ Cuautla, Morelos } & \multicolumn{3}{|c|}{ Santa Isabel Cholula, Puebla } \\
\hline & \multirow{2}{*}{$\frac{\text { Disease }(\%)^{\mathrm{x}}}{28 \mathrm{May}}$} & \multirow[b]{2}{*}{ AUDPC ${ }^{\mathbf{y}}$} & \multicolumn{2}{|c|}{ Disease $(\%)^{x}$} & \multirow[b]{2}{*}{ AUDPC $^{\mathbf{y}}$} & \multicolumn{2}{|c|}{ Disease $(\%)^{x}$} & \multirow[b]{2}{*}{ AUDPC $^{\mathbf{y}}$} \\
\hline & & & 8 October & 5 November & & 8 October & 5 November & \\
\hline Acibenzolar-s-methyl & $2.0 \mathrm{cdef}$ & $11.8 \mathrm{bcde}$ & 0.0 & $7.5 \mathrm{c}$ & $8.6 \mathrm{c}$ & $5.0 \mathrm{a}$ & $32.0 \mathrm{~b}$ & $23.6 \mathrm{a}$ \\
\hline Cyproconazole & $1.5 \mathrm{def}$ & 11.5 bcde & 0.0 & $0.5 \mathrm{c}$ & $7.9 \mathrm{c}$ & $6.5 \mathrm{a}$ & $0.0 \mathrm{c}$ & $18.3 \mathrm{bc}$ \\
\hline Difenoconazole & $6.8 \mathrm{ab}$ & $13.1 \mathrm{abcd}$ & 0.0 & $2.3 \mathrm{c}$ & $12.9 \mathrm{~b}$ & $0.5 \mathrm{bc}$ & $0.0 \mathrm{c}$ & $8.5 \mathrm{de}$ \\
\hline Epoxiconazole & $6.3 \mathrm{abc}$ & $13.8 \mathrm{ab}$ & 0.0 & $0.3 \mathrm{c}$ & $7.6 \mathrm{c}$ & $0.8 \mathrm{bc}$ & $0.0 \mathrm{c}$ & $13.0 \mathrm{~cd}$ \\
\hline Chlorothalonil & 2.8 bcdef & 11.5 bcde & 0.5 & $22.0 \mathrm{~b}$ & $15.1 \mathrm{~b}$ & $7.3 \mathrm{a}$ & $36.3 \mathrm{~b}$ & $23.4 \mathrm{ab}$ \\
\hline Flutolanil & $3.0 \mathrm{bcdef}$ & $11.6 \mathrm{bcde}$ & 0.3 & $3.5 \mathrm{c}$ & $13.1 \mathrm{~b}$ & $0.8 \mathrm{bc}$ & $1.0 \mathrm{c}$ & $12.3 \mathrm{de}$ \\
\hline Azoxystrobin + difenoconazole & $1.3 \mathrm{def}$ & $11.0 \mathrm{cde}$ & 0.0 & $0.0 \mathrm{c}$ & $7.0 \mathrm{c}$ & $3.8 \mathrm{ab}$ & $0.0 \mathrm{c}$ & $11.3 \mathrm{de}$ \\
\hline Azoxystrobin + epoxiconazole & $0.3 \mathrm{f}$ & $10.6 \mathrm{e}$ & 0.0 & $0.0 \mathrm{c}$ & $7.0 \mathrm{c}$ & $0.0 \mathrm{c}$ & $0.0 \mathrm{c}$ & $7.3 \mathrm{e}$ \\
\hline Azoxystrobin + propiconazole & $0.3 \mathrm{f}$ & $10.9 \mathrm{de}$ & 0.0 & $0.0 \mathrm{c}$ & $7.0 \mathrm{c}$ & $0.0 \mathrm{c}$ & $0.5 \mathrm{c}$ & $7.1 \mathrm{e}$ \\
\hline Fluoxastrobin + myclobutanil & $5.5 \mathrm{abcd}$ & $13.6 \mathrm{ab}$ & 0.0 & $0.3 \mathrm{c}$ & $7.6 \mathrm{c}$ & $0.0 \mathrm{c}$ & $1.0 \mathrm{c}$ & $13.0 \mathrm{~cd}$ \\
\hline Oxycarboxin + tebuconazole & $2.0 \mathrm{cdef}$ & 11.6 bcde & 0.0 & $0.8 \mathrm{c}$ & $7.4 \mathrm{c}$ & $0.8 \mathrm{bc}$ & $0.0 \mathrm{c}$ & $7.5 \mathrm{e}$ \\
\hline Oxycarboxin + trifloxystrobin & $1.0 \mathrm{ef}$ & $10.8 \mathrm{e}$ & 0.0 & $0.0 \mathrm{c}$ & $7.0 \mathrm{c}$ & $0.0 \mathrm{c}$ & $1.8 \mathrm{c}$ & $9.1 \mathrm{de}$ \\
\hline Chlorothalonil + epoxiconazole & $2.8 \mathrm{bcdef}$ & 12.4 abcde & 0.0 & $0.0 \mathrm{c}$ & $7.0 \mathrm{c}$ & $0.5 \mathrm{bc}$ & $0.3 \mathrm{c}$ & $8.9 \mathrm{de}$ \\
\hline Chlorothalonil + propiconazole & $5.0 \mathrm{bcde}$ & $13.3 \mathrm{abc}$ & 0.0 & $0.0 \mathrm{c}$ & $7.0 \mathrm{c}$ & $0.8 \mathrm{bc}$ & $2.5 \mathrm{c}$ & $9.1 \mathrm{de}$ \\
\hline Nontreated control & $9.8 \mathrm{a}$ & $14.4 \mathrm{a}$ & 1.3 & $42.5 \mathrm{a}$ & $20.6 \mathrm{a}$ & $7.0 \mathrm{a}$ & $58.8 \mathrm{a}$ & $27.3 \mathrm{a}$ \\
\hline $\operatorname{LSD}(P=0.05)$ & 4.3 & 2.3 & n.s. & 12.2 & 3.5 & 3.7 & 12.6 & 5.3 \\
\hline \multicolumn{9}{|l|}{ One-way ANOVA $(P>F)^{\mathrm{z}}$} \\
\hline \multirow{2}{*}{\multicolumn{9}{|c|}{ Contrasts }} \\
\hline & & & & & & & & \\
\hline 14 treatments vs. control & $<0.0001$ & $<0.0001$ & & $<0.0001$ & $<0.0001$ & 0.0013 & $<0.0001$ & $<0.0001$ \\
\hline 6 single vs. 8 combination treatments & 0.0973 & 0.2988 & & 0.0257 & $<0.0001$ & 0.0003 & 0.0001 & $<0.0001$ \\
\hline Singles: 5 fungicides vs. acibenzolar & 0.2928 & 0.5077 & & 0.5918 & 0.1338 & 0.1102 & $<0.0001$ & $<0.0001$ \\
\hline Singles: 3 DMIs vs. chlorothalonil and & & & & & & & & \\
\hline flutolanil & 0.1853 & 0.0911 & & 0.0090 & 0.0001 & 0.2395 & $<0.0001$ & 0.0080 \\
\hline Singles: chlorothalonil vs. flutolanil & 0.9122 & 0.9103 & & 0.0080 & 0.2448 & 0.0010 & $<0.0001$ & $<0.0001$ \\
\hline \multicolumn{9}{|l|}{ Combinations: 4 DMI + QoI vs. } \\
\hline 2 chlorothalonil and 2 oxycarboxin & 0.4418 & 0.3998 & & 0.9703 & 0.9416 & 0.6369 & 0.8248 & 0.4360 \\
\hline $\begin{array}{l}\text { DMI combinations: } 3 \text { azoxystrobin vs. } \\
\text { fluoxastrobin }\end{array}$ & 0.0105 & 0.0033 & & 0.9636 & 0.6541 & 0.4101 & 0.8803 & 0.0373 \\
\hline DMI combinations: 3 azoxystrobin vs. & & & & & & & & \\
\hline 2 chlorothalonil & 0.0286 & 0.0079 & & 1.0000 & 1.0000 & 0.6016 & 0.7824 & 0.7815 \\
\hline Combinations: 3 azoxystrobin + & & & & & & & & \\
\hline DMI vs. 2 oxycarboxin & 0.5321 & 0.6213 & & 0.9310 & 0.8649 & 0.4654 & 0.8713 & 0.8897 \\
\hline Combinations: 2 chlorothalonil + & & & & & & & & \\
\hline $\begin{array}{l}\text { DMI vs. } 2 \text { oxycarboxin } \\
\text { Oxycarboxin combinations: }\end{array}$ & 0.1434 & 0.0429 & & 0.9370 & 0.8765 & 0.8486 & 0.9169 & 0.7042 \\
\hline $\begin{array}{l}\text { Oxycarboxin combinations: } \\
\text { trifloxystrobin vs. tebuconazole }\end{array}$ & 0.6596 & 0.4318 & & 0.9109 & 0.8261 & 0.6857 & 0.7962 & 0.5263 \\
\hline
\end{tabular}

${ }^{w}$ Independent crops of gladiolus were grown in the spring and fall at all three sites. Fungicides were applied five times in the spring and four times in the fall at approximately 2-week intervals. Application dates in spring were 19 March, 2 April, 16 April, 30 April, and 14 May; application dates in fall were 17 September, 1 October, 15 October, and 29 October.

${ }^{\mathrm{x}}$ Foliage disease means are from all plants in four replicate plots. Means were separated with Fisher's protected least significant difference (LSD) at $P=$ 0.05 ; means in each column followed by the same letter are not significantly different; $n$.s. $=$ not significant.

y AUDPC was converted from a rust severity scale (1 to 12) following the methods of Shaner and Finney (24).

${ }^{\mathrm{z}}$ Each datum set was analyzed by one-way analysis of variance (ANOVA) with single-degree-of-freedom linear contrasts used for comparisons of specific treatments. DMI $=$ all active ingredients that are demethylation inhibitors, $\mathrm{QoI}=$ all active ingredients that are quinone outside inhibitors, singles $=$ treatments with individual products, combinations $=$ treatments using a combination of two products, $P>F$ is the probability of a greater $F$ value occurring. 
agement might have been realized if combinations or rotations of products had been used.

Triazole fungicides, one type of chemistry within the DMI group of fungicides (FRAC Code 3), inhibit ergosterol biosynthesis and development of cell membranes in target fungi (6). This chemical group also affects the permeability of the cell membrane or causes its dissolution, with the consequent loss of cell contents (10). This feature, combined with relatively easy mobility within the plant (i.e., most are upwardly systemic), gives this group of fungicides protective, curative, and limited eradicant properties $(3,14)$. Propiconazole and epoxiconazole are two triazoles that have been used for management of white rust on chrysanthemum caused by Puccinia horiana $(6,12)$. Propiconazole also has protective and curative effects against leaf rust of blackberry caused by Phragmidium violaceum (28). Several triazoles, including difenoconazole, epoxiconazole, and tebuconazole, were successfully employed for management of faba bean rust, which is caused by another species of Uromyces, U. viciae-fabae (7).

In the present study, the succinate dehydrogenase inhibitor flutolanil (a phenyl-benzamide fungicide), used alone or in rotation with a triazole fungicide, significantly reduced rust development in six trials at three locations over 2 years. Flutolanil is sold in the United States as ProStar (Bayer Environmental Science) for use on ornamental crops to manage rusts, Rhizoctonia spp., and Sclerotium rolfsii, but it is not registered in Mexico to manage rusts on ornamental crops. It is a systemic fungicide that moves upward in the xylem and has both preventive and curative properties $(11,14)$. Flutolanil prevents fungal growth and host penetration and also induces collapse of hyphae at infection sites $(11,14)$. Based on the efficacy against gladiolus rust by flutolanil we observed in our studies, it would be advantageous for this product to be registered and available in Mexico as another disease management option.

High disease pressure at both locations in 2010 probably contributed to the high levels of disease observed in fungicide-treated plots. For example, the percentage of foliage exhibiting disease symptoms for some treatments was higher than 40 and $50 \%$ in Atlixo and Cuautla, respectively. All fungicide treatments in these two trials had over $30 \%$ of foliage with disease symptoms and signs. Gladiolus has a relatively short growing season (7 to 10 weeks) before the onset of flower harvest, which underscores the need for active disease scouting and the use of preventative fungicide applications to slow the progress of rust epidemics.

All the fungicide combinations tested in the present study significantly reduced rust development on gladiolus plants. Combinations included a triazole (difenoconazole, epoxiconazole, myclobutanil, propiconazole, or tebuconazole) mixed with a QoI (azoxystrobin or fluoxastrobin), oxycarboxin, or chlorothalonil and a QoI (trifloxystrobin) mixed with oxycarboxin. QoI fungicides have shown excellent efficacy for managing Puccinia rusts on other ornamental plants, including daylily rust ( $P$. hemerocallidis), geranium rust ( $P$. pelargonii-zonalis), and sunflower rust $(P$. helianthi) (15). These fungicides inhibit mitochondrial respiration, blocking the transfer of electrons between cytochrome $\mathrm{B}$ and cytochrome $\mathrm{C}_{1}$, thereby preventing the formation of ATP (5). QoI fungicides are effective at preventing germination of rust urediniospores. Azoxystrobin significantly reduced germination of urediniospores of $P$. hemerocallidis (4), and azoxystrobin and trifloxystrobin prevented germination of urediniospores of five species of Puccinia and Pucciniastrum (16). Azoxystrobin has good residual activity, providing up to 8 weeks of protection against certain plant pathogens, due to active cell absorption and systemic action in the plant (5).

Rotating single active ingredients or combinations of two active ingredients significantly reduced gladiolus rust development. Foliage disease levels were not observed above $4.3 \%$ at the Cuautla location or above $8.3 \%$ at the Santa Isabel Cholula location in 2012. Rotation of active ingredients is a component of label recommendations for many at-risk fungicides such as the QoIs and triazoles. Although resistance to QoI fungicides has not been reported in field strains of most rust pathogens (9), proper and responsible use of active ingredients in different mode-of-action groups will minimize the likelihood of fungicide resistance developing in target populations.

In conclusion, several fungicide active ingredients showed excellent efficacy against gladiolus rust in commercial field trials in Mexico. Combining two active ingredients with different modes of action and rotating individual active ingredients or combinations of active ingredients between applications seemed to improve the

Table 4. Percentage of foliage with rust symptoms caused by Uromyces transversalis and areas under disease progress curves (AUDPC) after different fungicides or combinations of fungicides were rotated for each of four applications at 2-week intervals in commercial gladiolus fields at two locations in Mexico in fall 2012

\begin{tabular}{|c|c|c|c|c|c|c|c|c|c|}
\hline \multirow{2}{*}{\multicolumn{4}{|c|}{ Fungicide active ingredients and application dates ${ }^{w}$}} & \multicolumn{3}{|c|}{ Cuautla, Morelos } & \multicolumn{3}{|c|}{ Santa Isabel Cholula, Puebla } \\
\hline & & & & \multicolumn{2}{|c|}{ Foliage disease $(\%)^{\mathrm{x}}$} & \multirow[b]{2}{*}{$\mathbf{A U D P C}^{\mathbf{y}}$} & \multicolumn{2}{|c|}{ Foliage disease $(\%)^{\mathrm{x}}$} & \multirow[b]{2}{*}{ AUDPC } \\
\hline 14 Sep & 28 Sep & 12 Oct & 26 Oct & 28 Sep & 26 Oct & & 28 Sep & 26 Oct & \\
\hline Tebucon + oxycarb & Tebucon + azoxy & Trifloxy + oxycarb & Myclo + fluox & $0.3 \mathrm{~b}$ & $0.5 \mathrm{~b}$ & $0.5 \mathrm{~b}$ & $0.3 \mathrm{de}$ & $2.5 \mathrm{bc}$ & $1.8 \mathrm{~b}$ \\
\hline Tebucon + oxycarb & Difen + azoxy & Trifloxy + oxycarb & Prop + azoxy & $0.0 \mathrm{~b}$ & $1.0 \mathrm{~b}$ & $0.5 \mathrm{~b}$ & 3.0 cde & $2.3 \mathrm{bc}$ & $6.1 \mathrm{~b}$ \\
\hline Tebucon + oxycarb & Epox + chloro & Trifloxy + oxycarb & Epox + azoxy & $0.0 \mathrm{~b}$ & $1.8 \mathrm{~b}$ & $0.9 \mathrm{~b}$ & $0.0 \mathrm{e}$ & $3.5 \mathrm{bc}$ & $3.5 \mathrm{~b}$ \\
\hline Tebucon + oxycarb & Prop + azoxy & Tebucon + oxycarb & Difen + azoxy & $4.3 \mathrm{~b}$ & $0.0 \mathrm{~b}$ & $6.3 \mathrm{~b}$ & $5.8 \mathrm{bc}$ & $0.0 \mathrm{c}$ & $8.0 \mathrm{~b}$ \\
\hline Tebucon + oxycarb & Myclo + fluox & Tebucon + oxycarb & Epox + azoxy & $4.0 \mathrm{~b}$ & $0.0 \mathrm{~b}$ & $4.5 \mathrm{~b}$ & $4.0 \mathrm{c}$ & $0.3 \mathrm{c}$ & $6.1 \mathrm{~b}$ \\
\hline Tebucon + oxycarb & Prop + chloro & Tebucon + oxycarb & Difen + azoxy & $0.5 \mathrm{~b}$ & $0.0 \mathrm{~b}$ & $0.8 \mathrm{~b}$ & $3.8 \mathrm{~cd}$ & $1.8 \mathrm{bc}$ & $6.4 \mathrm{~b}$ \\
\hline Flutol & Epox & Flutol & Cypro & $1.0 \mathrm{~b}$ & $1.0 \mathrm{~b}$ & $1.8 \mathrm{~b}$ & $8.0 \mathrm{~b}$ & $3.0 \mathrm{bc}$ & $12.8 \mathrm{~b}$ \\
\hline Flutol & Cypro & Flutol & Difen & $1.8 \mathrm{~b}$ & $0.8 \mathrm{~b}$ & $3.4 \mathrm{~b}$ & $8.3 \mathrm{~b}$ & $2.8 \mathrm{bc}$ & $16.4 \mathrm{~b}$ \\
\hline Flutol & Difen & Flutol & Epox & $0.5 \mathrm{~b}$ & $0.5 \mathrm{~b}$ & $0.8 \mathrm{~b}$ & $7.8 \mathrm{~b}$ & $4.5 \mathrm{~b}$ & $14.5 \mathrm{~b}$ \\
\hline Nontreated control & $\ldots$ & $\ldots$ & $\ldots$ & $10.5 \mathrm{a}$ & $35.3 \mathrm{a}$ & $97.6 \mathrm{a}$ & $15.3 \mathrm{a}$ & $81.5 \mathrm{a}$ & $215.0 \mathrm{a}$ \\
\hline $\operatorname{LSD}(P=0.05)$ & $\ldots$ & $\ldots$ & $\ldots$ & 4.3 & 8.2 & 22.9 & 3.6 & 3.7 & 17.5 \\
\hline \multicolumn{10}{|l|}{ ANOVA $(P>F)^{\mathrm{Z}}$} \\
\hline Treatments & $\ldots$ & $\ldots$ & $\ldots$ & 0.0049 & $<0.0001$ & $<0.0001$ & $<0.0001$ & $<0.0001$ & $<0.0001$ \\
\hline \multicolumn{10}{|l|}{ Contrasts } \\
\hline Treatments vs. control & $\ldots$ & $\ldots$ & $\ldots$ & 0.0712 & 0.0712 & $<0.0001$ & $<0.0001$ & $<0.0001$ & $<0.0001$ \\
\hline 6 combs. vs. 3 singles & $\ldots$ & $\ldots$ & $\ldots$ & 0.7450 & 0.9270 & 0.9673 & 0.0012 & 0.0598 & 0.1480 \\
\hline
\end{tabular}

${ }^{\mathrm{w}}$ Individual fungicides or a combination of two fungicides were applied on each of the four dates; Sep = September and Oct = October. Fungicide active ingredients used were azoxy $=$ azoxystrobin, cypro $=$ cyproconazole, chloro $=$ chlorothalonil, difen $=$ difenoconazole, epox $=$ epoxiconazole, flutol $=$ flutolanil, fluox $=$ fluoxastrobin, myclo $=$ myclobutanil, oxycarb = oxycarboxin, prop = propiconazole, tebucon = tebuconazole, and trifloxy $=$ trifloxystrobin.

${ }^{\mathrm{x}}$ Foliage disease means are from all plants in four replicate plots. Means were separated with Fisher's protected least significant difference (LSD) at $P=0.05$; means in each column followed by the same letter are not significantly different.

y AUDPC was converted from a rust severity scale (1 to 12) following the methods of Shaner and Finney (24).

${ }^{\mathrm{z}}$ Each datum set was analyzed by one-way analysis of variance (ANOVA) with single-degree-of-freedom linear contrasts used for comparisons of specific treatments, singles $=$ treatments using an individual product for each application, combs. = treatments using a combination of two products for each application, $P>F$ is the probability of a greater $F$ value occurring. 
performance of these fungicides. Proper use of these different fungicide chemistries by growers should reduce the impact of rust epidemics in gladiolus fields in Mexico and also reduce the potential for accidental introductions of $U$. transversalis into the United States on plants and cut flowers grown in Mexico.

\section{Acknowledgments}

This research was funded by a cooperative agreement from the United States Department of Agriculture-Animal and Plant Health Inspection Service. We thank S. Villegas-Elizalde for technical assistance in the field trials and J. Davis for assistance with statistical analyses.

\section{Literature Cited}

1. Beilharz, V., Parberry, D. G., and Pascoe, I. G. 2001. Gladiolus rust (caused by Uromyces transversalis) in eastern Australia. Australas. Plant Pathol. 30:267-270.

2. Blomquist, C. L., Thomas, S. L., McKemy, J. M., Nolan, P. A., and LuqueWilliams, M. 2007. First report of Uromyces transversalis, causal agent of gladiolus rust, in San Diego County, California. Plant Dis. 91:1202.

3. Bonde, M. R., Peterson G. L., Rizvi S. A., and Smilanik, J. L. 1995. Myclobutanil as a curative agent of chrysanthemum white rust. Plant Dis. 79:500505.

4. Buck, J. W., and Williams-Woodward, J. L. 2003.The effect of fungicides on urediniospore germination and disease development of daylily rust. Crop Prot. 22:135-140.

5. Clough, J. M., and Godfrey, C. R. A. 1998. The strobilurin fungicides. Pages 109-148 in: Fungicidal Activity: Chemical and Biological Approaches to Plant Protection. D. Hutson and J. Miyamoto, eds. John Wiley and Sons Ltd., West Sussex, England.

6. Dickens, J. S. W. 1990. Studies on the chemical control of chrysanthemum white rust caused by Puccinia horiana. Plant Pathol. 39:434-442.

7. Emeran, A. A., Sillero, J. C., Fernández-Aparicio, M., and Rubiales, D. 2011. Chemical control of faba bean rust (Uromyces viciae-fabae). Crop Prot. 30:907-912.

8. Ferreira, J. F., and Rijkenberg, F. H. J. 1991. Ultrastructural morphology of Uromyces transversalis infection of resistant and susceptible gladiolus hosts and a non-host, Zea mays. Phytopathology 81:596-602.

9. Grasso, V., Palermo, S., Sierotzki, H., Garibaldi, A., and Gisi, U. 2006. Cytochrome b gene structure and consequences for resistance to Qo inhibitor fungicides in plant pathogens. Pest. Manage. Sci. 62:465-472.

10. Hewitt, H. G. 1998. Fungicides in Crop Protection. CAB International, New York.

11. Hirooka, T., Miyagi, Y., Araki, F., and Kunoh, H. 1989. Biological mode of action of flutolanil in its systemic control of rice sheath blight. Phytopathology 79:1091-1094.

12. Lam, C. H., and Lim, T. K. 1993. Efficacy of hexaconazole for the control of white rust on chrysanthemum and powdery mildew on roses. Int. J. Pest Manage. 39:156-160.

13. Lawrence, G. B. 2005. Uromyces transversalis Assessment of the Risk of Introduction Recommendations for Risk Mitigation for Gladiolus spp. Cut
Flowers and Propagative Material from Mexico. A Qualitative, OrganismBased Pathway Risk Assessment. USDA Plant Protection and Quarantine. Ad Hoc request No. 29. http://www.freshfromflorida.com/pi/enpp/path ology/images/gladrustmexpra.pdf

14. Mendoza, Z. C. 1990. Fungicidas sistémicos y su modo de acción. Universidad de Chapingo, Departamento de Parasitología Agrícola, Enseñanza e Investigación Parasitología, Chapingo, México.

15. Mueller, D. S., Jeffers, S. N., and Buck, J. W. 2004. Effect of timing of fungicide applications on development of rust on daylily, geranium, and sunflower. Plant Dis. 88:657-661.

16. Mueller, D. S., Jeffers, S. N., and Buck, J. W. 2005. Toxicity of fungicides to urediniospores of six rust fungi that occur on ornamental crops. Plant Dis. 89:255-261

17. Ortega, C. S. 2010. Métodos de inoculación y evaluación de extractos botánicos e isotiocianatos de la familia Brasicacea en el control de la roya del gladiolo. Rev. Chapingo Ser. Hortic. 16:13-21.

18. Rizvi, A. S., Man-Son-Hing, A., Jackson, A. S., Parra, G. R., Schartzburg, K. A., Brown, L. G., Sullivan, M. J., Duffie, L. E., Kosta, K. L., Clark, R, Kaitany, R., and Schubert, T. 2007. Gladiolus rust (Uromyces transversalis): a national management plan for exclusion and eradication. USDA APHIS PPQ. http://www.aphis.usda.gov/plant_health/plant_pest_info/gladiolus_ rust/downloads/grust-ntlmgntplan.pdf

19. Rodriguez-Alvarado, G., Fernández-Pavía, S. P., Valenzuela-Vázquez, M. and Loya-Ramirez, J. G. 2006. First report of gladiolus rust caused by Uromyces transversalis in Michoacán, México. Plant Dis. 90:687.

20. Rubí-Ramos, J. A. 2006. Manejo químico de la roya del gladiolo [Uromyces transversalis Thümen (Winter)] en Atlixco, Puebla. M.Sc. thesis, Departamento de Parasitología Agrícola, Universidad Autónoma Chapingo, Chapingo, México.

21. SAGARPA-SENASICA, 2005. Roya del gladiolo Uromyces transversalis. Cartilla de gladiolo. No.127. Col. del Carmen, Coyoacán, México.

22. Schubert, T. S., Leahy, R. M., Davison, D. A., Silagyi, A. J., and Killgore, E. M. 2007. Gladiolus rust caused by Uromyces transversalis makes first nearctic appearance in Florida. Plant Dis. 91:1201.

23. Servicio de Información Agroalimentaria y Pesquera (SIAP). 2010. Disponible en la página. http://www.siap.gob.mx/index.php?option=com content\&view $=$ article $\&$ id $=10 \&$ Itemid $=15$

24. Shaner, G., and Finney, R. E. 1977. The effect of nitrogen fertilization on the expression of slow-mildewing resistance in Knox wheat. Phytopathology 67:1051-1056.

25. Tooley, P. W., and Grau, C. R. 1984. Field characterization of rate-reducing resistance to Phytophthora megasperma f. sp. glycinea in soybean. Phytopathology 74:1201-1208.

26. Valencia-Botín, A., Buck, J., Jeffers, S., and Palmer, C. 2011. Managing gladiolus rust in Mexico with fungicides. (Abstr.) Phytopathology 101:S181

27. Valencia-Botín, A. J., Buck, J. W., Jeffers, S. N., and Palmer, C. L. 2012 Efficacy of fungicides and mixtures of fungicides for management of gladiolus rust in Mexico. (Abstr.) Phytopathology 102:S125.

28. Washington, W. S. 1987. Susceptibility of Rubus species and cultivars to blackberry leaf rust (Phragmidium violaceum) and its control by fungicides. J. Phytopathol. 118:265-275. 